\title{
Evidence Synthesis of Digital Interventions to Mitigate the Negative Impact of the COVID-19 Pandemic on Public Mental Health: Rapid Meta-review
}

Christian Rauschenberg ${ }^{1,2^{*}}$, MSc; Anita Schick ${ }^{1 *}$, PhD, Dipl-Psych; Dusan Hirjak ${ }^{3}$, MD; Andreas Seidler ${ }^{4}$, MD, MPH; Isabell Paetzold ${ }^{1}$, MSc; Christian Apfelbacher ${ }^{5}$, PhD, Dr sc hum, MSc, MA; Steffi G Riedel-Heller ${ }^{6}$, MD, MPH; Ulrich Reininghaus ${ }^{1,7,8}, \mathrm{PhD}, \mathrm{MSc}$, Dipl-Psych

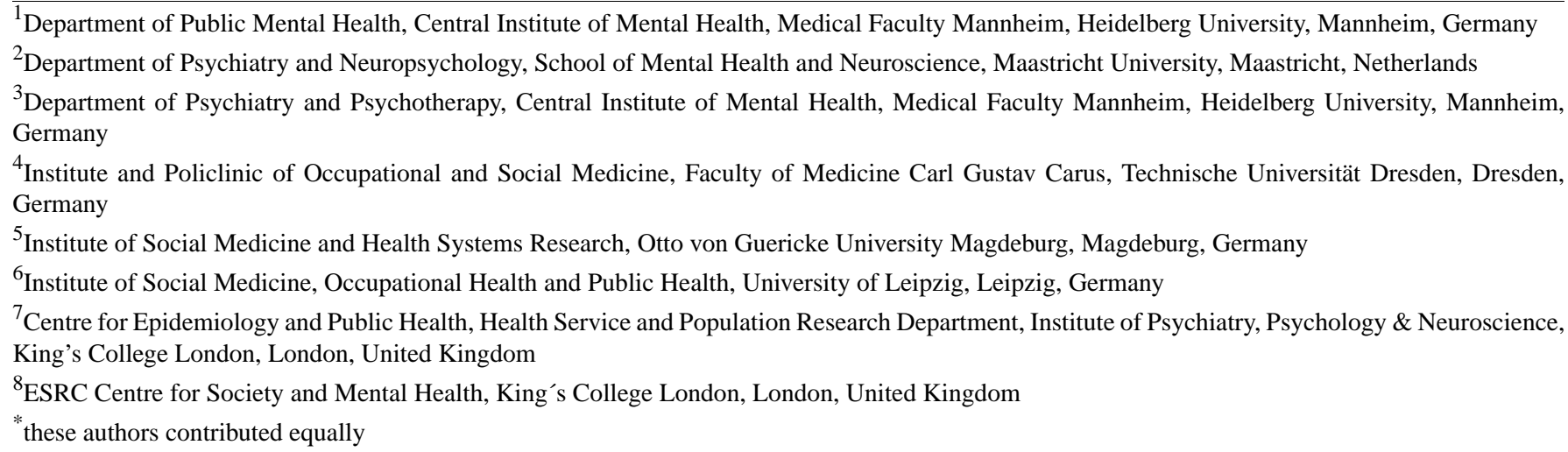

Corresponding Author:

Christian Rauschenberg, MSc

Department of Public Mental Health

Central Institute of Mental Health

Medical Faculty Mannheim, Heidelberg University

J5

Mannheim, 68159

Germany

Phone: 4962117031929

Email: christian.rauschenberg@zi-mannheim.de

\section{Abstract}

Background: Accumulating evidence suggests the COVID-19 pandemic has negative effects on public mental health. Digital interventions that have been developed and evaluated in recent years may be used to mitigate the negative consequences of the pandemic. However, evidence-based recommendations on the use of existing telemedicine and internet-based (eHealth) and app-based mobile health (mHealth) interventions are lacking.

Objective: The aim of this study was to investigate the theoretical and empirical base, user perspective, safety, effectiveness, and cost-effectiveness of digital interventions related to public mental health provision (ie, mental health promotion, prevention, and treatment of mental disorders) that may help to reduce the consequences of the COVID-19 pandemic.

Methods: A rapid meta-review was conducted. The MEDLINE, PsycINFO, and CENTRAL databases were searched on May 11, 2020. Study inclusion criteria were broad and considered systematic reviews and meta-analyses that investigated digital tools for health promotion, prevention, or treatment of mental health conditions and determinants likely affected by the COVID-19 pandemic.

Results: Overall, 815 peer-reviewed systematic reviews and meta-analyses were identified, of which 83 met the inclusion criteria. Our findings suggest that there is good evidence on the usability, safety, acceptance/satisfaction, and effectiveness of eHealth interventions. Evidence on mHealth apps is promising, especially if social components (eg, blended care) and strategies to promote adherence are incorporated. Although most digital interventions focus on the prevention or treatment of mental 
disorders, there is some evidence on mental health promotion. However, evidence on process quality, cost-effectiveness, and long-term effects is very limited.

Conclusions: There is evidence that digital interventions are particularly suited to mitigating psychosocial consequences at the population level. In times of physical distancing, quarantine, and restrictions on social contacts, decision makers should develop digital strategies for continued mental health care and invest time and efforts in the development and implementation of mental health promotion and prevention programs.

(J Med Internet Res 2021;23(3):e23365) doi: 10.2196/23365

\section{KEYWORDS}

COVID-19; mHealth; eHealth; telemedicine; prevention; mental health promotion; intervention; digital mental health; digital intervention; public mental health

\section{Introduction}

Measures to prevent and control infections during the COVID-19 pandemic such as physical distancing, quarantine, and restrictions on social contacts can have a negative impact on public mental health [1]. This includes an increase in depression, anxiety, loneliness, and perceived stress [2] as well as in risk behaviors such as cannabis and alcohol use [3] in the population. In addition to the immediate effects of the infection control measures, further negative consequences for mental health are to be expected due to the more direct, deleterious effects of COVID-19 (eg, illness anxiety, contamination fears) as well as the economic downturn and recession [4]. Recently reported restrictions in access to, and continuity of, care for individuals with mental disorder caused by infection prevention and control measures in some countries are an additional cause for concern $[3,5,6]$.

Digital interventions that do not require face-to-face contact may play an important role in improving public mental health at times of infection prevention and control measures. They can be broadly grouped as telemedicine and internet-based interventions (hereafter eHealth interventions) [7] and app-based mobile health (mHealth) interventions delivered using smartphones or other mobile devices [8]. These interventions provide a unique opportunity for delivering low-threshold, public mental health care tailored to individual needs and contexts in daily life, outside the clinic [9], even under the restrictive conditions of the COVID-19 pandemic. As smartphones are mostly in close proximity to users, and accessible whenever and wherever it is convenient, the use of mHealth apps in particular represents a powerful approach that allows for the real-time and real-world delivery of intervention components in individuals' daily lives.

Digital tools may help to mitigate negative psychosocial consequences most effectively if intervention strategies are not only targeted at vulnerable individuals in a clinically high-risk state or with a mental disorder but also at the population level. More specifically, following the seminal "population strategy" advocated by Rose [10], even a small shift in the population's mean level of mental health, which is continuously distributed in the population, may lead to a substantial reduction of the prevalence of mental health problems. If applied to the current pandemic, a scalable digital public mental health approach may contribute to lower rates of mental disorders by targeting important determinants and shifting the mean level of mental health in the population.

In order to minimize the negative impact of the COVID-19 pandemic on the mental health of the population, digital interventions can be used in the following areas of public mental health provision: primary prevention strategies, including (1) mental health promotion and literacy at the population level; (2) indicated, selective, or universal prevention targeting high-risk individuals, subpopulations, or the entire population, respectively, as well as secondary and tertiary prevention strategies, including (3) treatment and preventive services for people with mental disorders. Indeed, evidence from ad hoc surveys suggests that digital interventions for improving public mental health are urgently needed to address the psychosocial consequences of the COVID-19 pandemic [1-3,11,12]. For example, findings from the serial cross-sectional survey German COVID-19 Snapshot Monitoring (COSMO Germany [13]) suggest strong concerns about the economy, social inequalities, and the health care system as well as high levels of psychological distress in the adult general population, particularly among young people $[14,15]$. Another representative survey (Norstatpanel) found that a staggering $38 \%$ of youth met the criteria for moderate or severe mental health problems, even after the most restrictive infection control measures had been lifted [16]. Furthermore, the reported social isolation during the COVID-19 pandemic was associated with levels of psychological distress in a dose-response fashion [16]. Recent evidence also suggests a high subjective demand for digital mental health interventions in the general population and people with a mental disorder [17,18], which is matched with a high and rapidly growing number of mHealth apps available in major app stores, with the strongest growth having been noted for mHealth apps [19]. It has further been reported that the demand for mHealth apps has increased globally by $49 \%$ during the COVID-19 pandemic [20], with $73 \%$ of psychologically distressed and socially isolated youth in the Norstatpanel survey indicating the use of mHealth apps to be helpful in coping with the ongoing COVID-19 pandemic [16].

Taken together, based on the evidence presented, there is an urgent need for, and high potential in, using digital interventions to improve public mental health and mitigate the negative psychosocial impact of the COVID-19 pandemic. However, evidence-based recommendations for the use of digital interventions during public health crises, including this ongoing pandemic, is currently lacking. The present meta-review aimed 
to synthesize the available evidence on the theoretical and empirical base of interventions, quality assessments from the user perspective (ie, acceptability, usability, satisfaction), safety, effectiveness, and cost-effectiveness of digital interventions in the area of public mental health provision (ie, mental health promotion and prevention of and treatment for mental disorder).

\section{Methods}

\section{Overview}

A rapid meta-review of systematic reviews on digital public mental health interventions was conducted. For this, PRISMA (Preferred Reporting Items for Systematic Reviews and Meta-Analyses [21]) was used as a guideline for reporting findings. In line with the current state of the art in the development and evaluation of complex digital mental health interventions [8], the following criteria to review the available evidence were used: theoretical and evidence base, quality assessments from the user perspective (ie, acceptability, usability, satisfaction), safety, effectiveness, and cost-effectiveness.

\section{Search Strategy and Selection Criteria}

The MEDLINE, PsycINFO, and CENTRAL databases were searched for systematic reviews and meta-analyses published in the English and German languages from inception to April 2020. An extensive search of bibliographic databases was performed using queries that combined search terms on mental health, public mental health provision, digital eHealth/mHealth interventions (Multimedia Appendix 1), and high-quality reviews (ie, systematic review, meta-analysis) using logical operators. In doing so, database-specific queries were used to ensure semantic equivalence. The queries were launched on May 11, 2020, covering results until April 2020. The results were obtained, and duplicates were removed. References written in English and German were included. No other filters or restrictions were applied.
The search criteria were purposefully broad and considered systematic reviews and meta-analyses that investigated digital tools for health promotion, prevention, or treatment of mental health conditions and determinants likely affected by the COVID-19 pandemic (eg, depression, anxiety, psychosis, substance misuse, self-harm, well-being, quality of life, self-esteem, loneliness). Titles and abstracts were screened for inclusion by 1 reviewer (a research assistant). Studies were included if they were published in a peer-reviewed journal, contained original findings examining the theoretical and evidence base, quality from the user perspective (ie, acceptability, usability, satisfaction), safety, effectiveness, or cost-effectiveness of digital mHealth and eHealth interventions. Due to the rapid meta-review format of our study, conclusions drawn by the authors of the included systematic reviews were reported. The included articles had to be systematic reviews and/or meta-analyses that followed established reporting guidelines (eg, PRISMA [21]). Because of time constraints and the rapid meta-review format of this study, a second reviewer (CR) independently screened a randomly selected subset (40\%) of identified studies. The references were categorized as "eligible," "query," and "not eligible." Inclusion and exclusion criteria were applied to references that were queried or eligible. Reviewers were blinded, and potential discrepancies in selection decisions were discussed with another member of the research team. A pilot screening of a randomly selected subset of identified studies (around 5\%) was conducted to discuss decisions on categorizing studies at an early stage. As inclusion criteria were purposefully broad, discrepancies between the reviewers (CR and the research assistant) were very low. Full texts of potentially relevant articles were obtained, read, and assessed by 1 reviewer (CR), and data extraction was performed by 3 reviewers (CR and 2 research assistants under the close supervision of CR; see acknowledgments). Reviews and meta-analyses on preprint servers and gray literature were not included. The EndNote reference management software [22] was used to record reviewers' decisions, including reasons for exclusion. The study selection process was documented using the PRISMA flow diagram (Figure 1). 
Figure 1. Study selection.

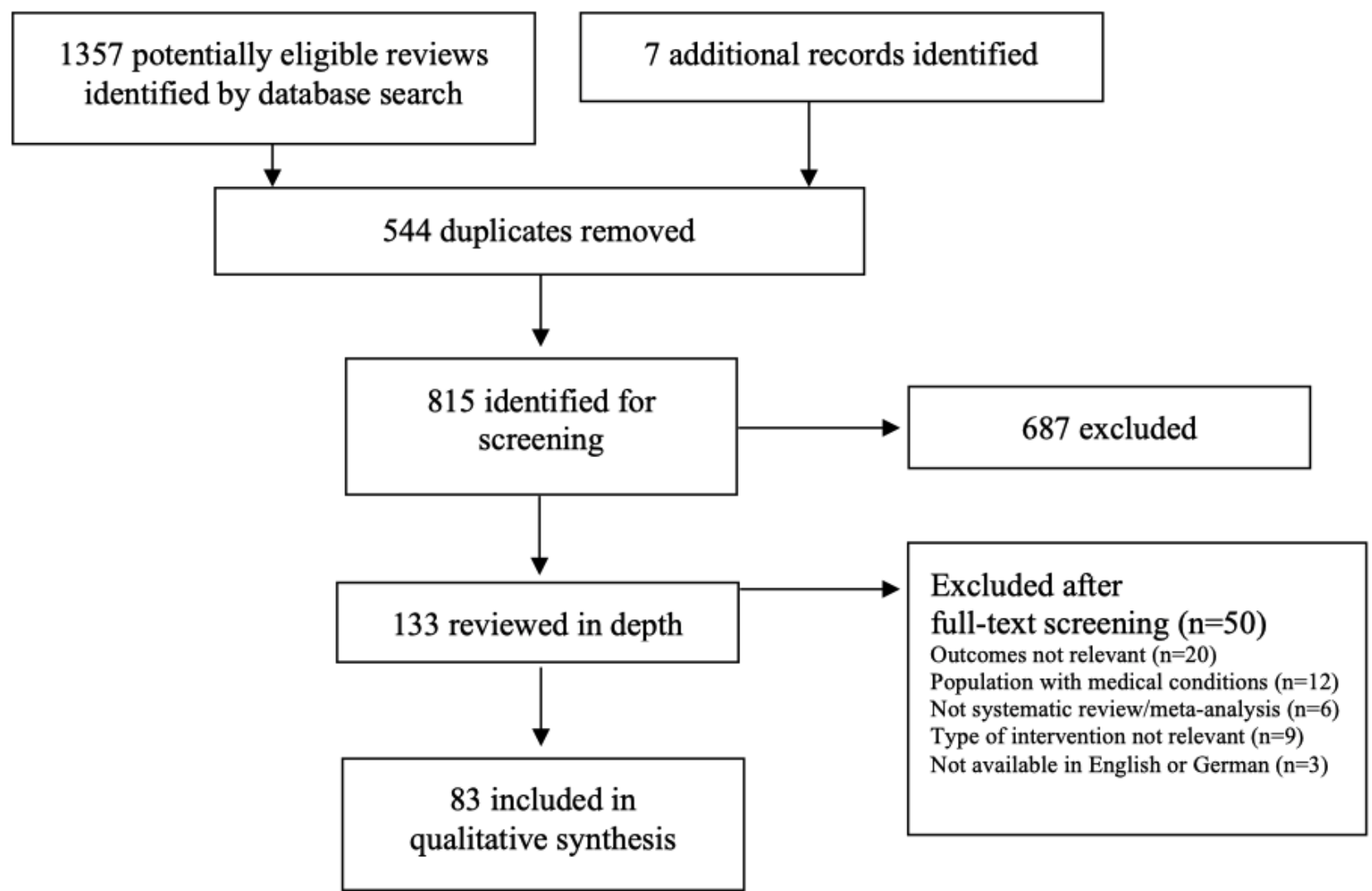

\section{Results}

\section{General Findings}

The search strategy of our meta-review on digital interventions yielded 815 peer-reviewed systematic reviews and meta-analyses (Figure 1). Of these, 83 references were included in the meta-review. Overall, 44 of the included reviews summarized findings on eHealth interventions and focused on interventions targeting depression $(n=19)$, anxiety $(n=22)$, problematic substance use $(n=11)$, and eating disorders $(n=2)$. Several reviews included interventions that targeted multiple mental health problems. In total, 16 reviews summarized findings on mHealth interventions and focused on depression $(n=2)$, anxiety $(\mathrm{n}=1)$, problematic substance use $(\mathrm{n}=1)$, and eating disorder $(n=1)$. Similarly, the majority of included reviews targeted various mental health domain. Furthermore, 23 of the included reviews jointly reported the effects of eHealth and mHealth interventions on various mental health outcomes (Multimedia Appendix 2). A complete summary of included reviews on eHealth, mHealth, and mixed interventions are shown in Multimedia Appendix 2, including findings on their theoretical and empirical base, user perspective, safety, effectiveness, and cost-effectiveness.

\section{Theoretical and Empirical Base}

For most eHealth and mHealth interventions in the area of mental health promotion and prevention as well as treatment of mental disorders, the theoretical and empirical base is explicitly mentioned in the description of interventions and are often informed by clinical guidelines and co-designed by service users and mental health professionals [23-26]. This primarily includes evidence-based procedures such as cognitive-behavioral therapy (CBT) or third-wave CBT $[23,25,26]$. In contrast to digital interventions developed by research groups, prominent mHealth apps available in major app stores do often not provide information on the theoretical or empirical base of their content [8,27-29]. Some mHealth apps may even be harmful and hinder healing processes (eg, asking users to do tasks that are too difficult to complete, presenting means for self-harm as well as lethal means, triggering unwanted distressing memories) $[8,27,28]$.

\section{Quality Assessments From the User Perspective}

Evidence from the included systematic reviews suggests moderate to high levels of acceptance, feasibility, and user satisfaction with eHealth and mHealth interventions for mental health promotion and prevention [30,31] as well as for the treatment of mental health problems [32-41]. This applies, in particular, for interventions including social components [32,42], strategies to promote user adherence [33,43], symptom monitoring $[44,45]$, or a blended-care approach [46].

In terms of safety, data sharing and data safety regulations, as well as aspects of eHealth/mHealth and clinical safety of interventions, were often not explicitly reported or systematically investigated in the identified systematic reviews [47-49] (Multimedia Appendix 2). The descriptions of many eHealth interventions do not make explicit reference to prevailing regulations and clinical guidelines [50]. Furthermore, there is evidence that mHealth apps available in major app stores use problematic data sharing and privacy practices (eg, 
monetization of sensitive user data through analytics and advertising) [8,27,28].

\section{Effectiveness of eHealth Interventions}

There was good evidence on the effectiveness of telemedical and other eHealth interventions in the field of mental health promotion and prevention, as well as for the treatment of mental health conditions.

\section{Mental Health Promotion and Prevention}

There have been a number of systematic reviews that aimed to investigate the effectiveness of telemedical and eHealth interventions for mental health promotion and prevention. These interventions have primarily been shown to improve mental health [34], physical activity [34,35], well-being [36,37], stress $[23,38]$, depression $[23,36,38,51,52]$, anxiety $[23,36,38,51,52]$, and alcohol [24,53-56] and cannabis use [57,58] in the general population in addition to dysfunctional cognition and self-esteem in at-risk populations $[59,60]$. Importantly, effectiveness has been demonstrated across differing age groups, including adults [24,54,59] and adolescents from the general population [34,52,56,61-63], and effect sizes mostly ranged from small to medium. However, evidence on the use of eHealth interventions for the elderly is scarce, although findings from the identified reviews indicated some evidence on the effectiveness of eHealth interventions for reducing social isolation and increasing social participation of people aged 65 years and older [64], which may be of particular interest in the context of the COVID-19 pandemic.

\section{Treatment of Mental Health Conditions}

There was also strong evidence on the effectiveness of telemedical and eHealth interventions in the provision of treatment and services for people with mental disorder. This included anxiety disorders [65-68], depression [60,61,65-67,69-73], substance abuse [54,74-76], eating disorders [77], and severe mental illness [78], with overall small to medium effect sizes, not only with regard to the reduction of relevant symptoms but also improvements in dysfunctional cognition [60], self-esteem [60], and quality of life [66]. Some of the identified studies have even reported medium to large effect sizes for cognitive-behavioral eHealth interventions that aimed to reduce symptoms of depression [79].

The effectiveness of telemedicine interventions that use videoconference tools or the telephone has also been well documented in depressive [80-83], anxiety [80,83-85], and psychotic disorders [86], with comparable effects for online group and individual therapy sessions $[87,88]$, compared with conventional (offline) therapy sessions. Superior effectiveness was observed for interventions adopting a blended-care approach combining eHealth with conventional intervention components $[46,54,71]$.

Overall, findings suggest that the evidence on long-term effects and noninferiority compared to conventional therapy and active control conditions remains limited $[79,81,82,86,87]$. There is also limited evidence on the impact of telemedical and eHealth interventions on underlying processes and mechanisms of change [89].

\section{Effectiveness of mHealth Interventions}

While there is some initial evidence on the effectiveness of mHealth interventions to improve physical activity [90-95], stress appraisal [96,97], depression [26,96-100], anxiety $[25,26,96,97]$, and alcohol and substance use [55,96,98,101-103], with small to medium effect sizes in all areas of public mental health provision, the amount of research to investigate this issue remains, overall, limited [104-108]. Only a minority of mHealth interventions were found to use more advanced techniques (accelerometer, GPS) to inform the delivery of intervention components $[25,89,92]$. In addition, a substantial difference was found between mHealth apps available in major app stores, for which there is no or only very limited evidence on their effectiveness [29,108-111], and mHealth interventions developed by research groups. Similar to eHealth interventions, evidence on long-term effects and on underlying processes and mechanisms of action remains very limited.

\section{Cost-effectiveness}

There is some evidence on the cost-effectiveness of eHealth interventions for depression and anxiety in primary care settings when compared to care as usual and waiting list control conditions [51] as well as for a range of mental disorders when compared to conventional CBT $[112,113]$. However, as only a few systematic reviews have systematically investigated the cost-effectiveness of digital interventions to date, these findings should be interpreted with caution. While there is some evidence on the cost-effectiveness of mHealth interventions (eg, for digital monitoring and feedback in depression) from individual studies [18], evidence summarized at the level of systematic reviews is very limited.

\section{Discussion}

\section{Principal Results}

Evidence-based eHealth and mHealth interventions may play a central role in areas of public mental health provision (ie, mental health promotion, as well as prevention of and treatment for mental disorders) to mitigate the negative consequences of the COVID-19 pandemic. To date, however, evidence-based recommendations on existing digital interventions that have been developed and evaluated in recent years are lacking. This meta-review was the first to review the available evidence on the theoretical and empirical base, quality assessments from the user perspective (ie, acceptability, usability, satisfaction), safety, effectiveness, and cost-effectiveness of digital interventions in the area of public mental health provision, that is, mental health promotion at the population level, indicated, selective, or universal prevention targeting high-risk individuals, subpopulations, or the entire population as well as treatment and services for people with mental disorders.

First, there was robust evidence on the effectiveness of telemedical eHealth interventions and initial evidence on the effectiveness of mHealth interventions in relation to mental health outcomes likely affected by the COVID-19 pandemic (eg, anxiety, depression), especially if interventions are informed by clinical guidelines and co-designed by service users and 
mental health professionals. Second, effectiveness, acceptability, feasibility, and user satisfaction have been described to be particularly high if digital interventions are embedded in a therapeutic context and include some form of social interaction with a mental health professional (blended-care approach). Third, some of the included systematic reviews and meta-analyses suggest noninferiority of effectiveness for some eHealth interventions as compared to traditional face-to-face therapy, but further replication is needed before firm conclusions can be drawn. Thus, in order to exclude the risk of infection in the current public health crisis, clinicians and other health professionals may consider combining differing types of digital interventions (eg, counseling or psychotherapy using videoconference software augmented by a smartphone-based mHealth app) as this approach may be particularly promising given the current evidence base and reflects a novel digital version of the blended-care approach. However, more research is needed to investigate long-term treatment effects and effects of symptom monitoring on mental health outcomes. Notably, the evidence on the use of digital interventions for the elderly and children is very limited. This is an important finding as these age groups may be particularly challenged by the current pandemic. Fourth, most studies to date do not specifically investigate the additive effects on health-related outcomes when using more advanced techniques (eg, accelerometer, GPS) to further personalize the delivery of intervention components, gamification elements, and the integration of other technologies such as wearables, although it has been described to be potentially beneficial in some of the included reviews $[25,89,92,114]$. Fifth, the theoretical basis of most digital interventions that have been described in previous reviews were found to be CBTs or third-wave CBTs as they may be particularly amendable to translation into digital intervention components $[23,25,26]$. Thus, clinicians with an expertise in CBT techniques may find it easier to purposefully incorporate intervention components delivered using digital tools in their daily clinical routines. However, findings suggest that there is a need to further improve the theoretical foundation of digital intervention, particularly mHealth interventions publicly available in major app stores. Sixth, the data available on the process quality and cost-effectiveness of eHealth and mHealth interventions are limited. Seventh, users frequently report concerns about data safety and privacy [115]. While eHealth and mHealth interventions developed and evaluated by research groups generally comply with the General Data Protection Regulation (in European countries) and work in accordance with Good Clinical Practice standards, the contents of many mHealth apps currently available in major app stores do not explicitly refer to existing clinical guidelines and recommendations by learned societies $[50,116]$. There are a number of reviews that have concluded that mHealth apps have problematic data-sharing and privacy practices $[8,27,28]$ and that there may not only be a lack of quality of offered content but even harmful intervention components. In addition, although not specifically reported in included systematic reviews and meta-analyses, the recent surge in the use of popular and freely available platforms (eg, Zoom, Skype) rather than secured platforms to provide online mental health services may be another cause of concern [117] as these platforms mostly do not comply with national standards for sensitive patient data protection. In order to demonstrate user safety, clinical guidelines should be explicitly taken into account and advice by mental health professionals, learned societies, and IT (information technology) professionals actively incorporated. Overall, apps available in app stores should be used with caution due to risks in data and clinical safety as well as a lack of evidence on their effectiveness.

\section{Limitations}

This meta-review has several limitations. Because of time constraints and the rapid meta-review format of this study, the quality of included systematic reviews was not evaluated using established assessment tools (eg, the AMSTAR 2 [A Measurement Tool to Assess Systematic Reviews] checklist [118]). Along similar lines, the conclusions drawn in this meta-review on the quality of evidence are largely based on quality assessments undertaken in the included systematic reviews and meta-analyses. However, if the quality of evidence was not systematically evaluated using a standardized approach, it is indicated in Multimedia Appendix 2. Additionally, only 1 reviewer screened identified articles while a second reviewer independently screened a randomly selected subset (40\%) of studies. However, this meta-review was conducted in line with the state of the art of conducting rapid reviews [119]. Furthermore, the World Health Organization has explicitly recommended rapid reviews for evidence synthesis during the ongoing public health crisis, given these are urgently needed for policy makers and the public [120].

In considering the urgent need of continued access to mental health care for vulnerable individuals during the COVID-19 pandemic, and the importance of developing and implementing public mental health prevention and promotion strategies, digital interventions should be provided by public health services and routinely offered when infection control measures are implemented during pandemics. Since there is currently no direct evidence on digital interventions that aim to minimize the psychosocial impact of previous coronavirus and influenza virus outbreaks, digital interventions should be developed and evaluated by research groups in close collaboration with relevant stakeholders to ensure established standards for investigating quality from the user perspective, effectiveness, and cost-effectiveness are met. Importantly, evidence-based digital interventions are scalable and can be rapidly delivered at the population level. This may facilitate delivering personalized care and minimizing the negative impact of the COVID-19 pandemic on public mental health.

\section{Conclusions}

Decision makers and stakeholders, including policy makers, technology companies, and public health professionals, should join forces to develop evidence-based strategies for mental health care in the area of public mental health provision, especially in moments of public health crises. As studies from previous pandemics, as well as accumulating evidence from the COVID-19 pandemic, suggest a negative impact on public mental health, the development and implementation of mental health promotion and prevention strategies at the population level may be an important measure to improve public mental 
health. Digital interventions that incorporate contact with mental health staff in a blended-care approach may be particularly suited to alleviate mental health burden in help-seeking individuals. At times of COVID-19 and physical distancing measures, this may be translated into a digital blended-care approach by combining telemedical with internet-based eHealth or smartphone-based mHealth interventions. Furthermore, efforts should be made to systematically evaluate currently available digital interventions based on established criteria of digital mental health and mental health services research, as demonstrated by recent initiatives (eg, National Health Service Apps Library in the United Kingdom; Platform for Digital Health Applications in Germany; App Evaluation Database provided by the Division of Digital Psychiatry, Beth Israel Deaconess Medical Center, in the United States) [121-123]. This would systematize the search for evidence-based mHealth apps and thus allow clinicians and interested users to make more informed decisions on the quality of currently available digital interventions. There is also a need to carefully examine the role of social inequalities and the related digital divide as well as possible barriers (eg, disproportional access to necessary technologies, educational requirements, language skills, cultural factors, motor or cognitive impairments), which can influence the access to and use of the information platforms of digital mental health interventions.

\section{Acknowledgments}

The authors wish to thank research assistants Nina Müller and Viktoria Pöss for helping with data extraction. CR and UR contributed to the conception and design of the study. CR carried out the literature search and data extraction (with the help of Müller and Pöss). CR, AS, IP, and UR contributed to data interpretation and qualitative synthesis, and to the writing of the manuscript. CR and AS wrote the first draft of the manuscript. All authors contributed to critical revision of the manuscript and approved the final version. $\mathrm{CR}, \mathrm{AR}$, and UR guarantee the integrity of the work.

UR is supported by a Heisenberg professorship from the German Research Foundation (grant \#389624707). The funder had no role in study design, search strategy, synthesis of findings, or writing of the review. The corresponding author had full access to all search items in the review and had final responsibility for the decision to submit for publication.

This work was carried out as part of the COVID-19 Public Health Research Network, an ad hoc consortium of more than 25 scientific societies and organizations that are active in the field of public health. They bring together their expertise in research methods, epidemiology, statistics, social sciences, demography, and medicine. The COVID-19 Public Health Research Network represents thousands of scientists from Germany, Austria, and Switzerland.

\section{Conflicts of Interest}

None declared.

\section{Multimedia Appendix 1}

The full electronic search strategy for one database.

[DOCX File, 22 KB-Multimedia Appendix 1]

\section{Multimedia Appendix 2}

Complete summary of included reviews on eHealth, mHealth, and mixed interventions. Findings on target populations, intervention components, theoretical and evidence base on process/outcomes, primary outcomes and quality of evidence, secondary outcomes, quality from the user perspective, safety, and cost-effectiveness are shown.

[DOCX File, 82 KB-Multimedia Appendix 2]

\section{References}

1. Röhr S, Müller F, Jung F, Apfelbacher C, Seidler A, Riedel-Heller SG. [Psychosocial Impact of Quarantine Measures During Serious Coronavirus Outbreaks: A Rapid Review]. Psychiatr Prax 2020 May;47(4):179-189 [FREE Full text] [doi: 10.1055/a-1159-5562] [Medline: 32340047]

2. Brooks SK, Webster RK, Smith LE, Woodland L, Wessely S, Greenberg N, et al. The psychological impact of quarantine and how to reduce it: rapid review of the evidence. The Lancet 2020 Mar 14;395(10227):912-920. [doi: 10.1016/S0140-6736(20)30460-8] [Medline: 32112714]

3. Holmes EA, O'Connor RC, Perry VH, Tracey I, Wessely S, Arseneault L, et al. Multidisciplinary research priorities for the COVID-19 pandemic: a call for action for mental health science. The Lancet Psychiatry 2020 Jun 15;7(6):547-560 [FREE Full text] [doi: 10.1016/S2215-0366(20)30168-1] [Medline: 32304649]

4. McKibbin WJ, Fernando R. The Global Macroeconomic Impacts of COVID-19: Seven Scenarios. SSRN Journal. Preprint posted online Mar 4, 2020. [doi: 10.2139/ssrn.3547729] 
5. Luykx JJ, Vinkers CH, Tijdink JK. Psychiatry in Times of the Coronavirus Disease 2019 (COVID-19) Pandemic: An Imperative for Psychiatrists to Act Now. JAMA Psychiatry 2020 May 27;77(11):1097-1098. [doi: 10.1001/jamapsychiatry.2020.1225] [Medline: $\underline{32459359]}$

6. Yao H, Chen J, Xu Y. Patients with mental health disorders in the COVID-19 epidemic. The Lancet Psychiatry 2020 Apr;7(4):e21. [doi: 10.1016/S2215-0366(20)30090-0] [Medline: 32199510]

7. Mohr DC, Schueller SM, Montague E, Burns MN, Rashidi P. The behavioral intervention technology model: an integrated conceptual and technological framework for eHealth and mHealth interventions. J Med Internet Res 2014 Jun 05;16(6):e146 [FREE Full text] [doi: 10.2196/jmir.3077] [Medline: 24905070]

8. Kramer U, Borges U, Fischer F, Hoffmann W, Pobiruchin M, Vollmar HC. [DNVF-Memorandum - Health and Medical Apps]. Gesundheitswesen 2019 Oct;81(10):e154-e170. [doi: 10.1055/s-0038-1667451] [Medline: 31574556]

9. Myin-Germeys I, Klippel A, Steinhart H, Reininghaus U. Ecological momentary interventions in psychiatry. Curr Opin Psychiatry 2016 Jul;29(4):258-263. [doi: 10.1097/YCO.0000000000000255] [Medline: 27153125]

10. Rose G. Sick individuals and sick populations. Int J Epidemiol 2001 Jun;30(3):427-32; discussion 433. [doi: 10.1093/ije/30.3.427] [Medline: 11416056 ]

11. Wright L, Steptoe A, Fancourt D. Are we all in this together? Longitudinal assessment of cumulative adversities by socioeconomic position in the first 3 weeks of lockdown in the UK. J Epidemiol Community Health 2020 Sep;74(9):683-688 [FREE Full text] [doi: 10.1136/jech-2020-214475] [Medline: 32503892]

12. Pierce M, Hope H, Ford T, Hatch S, Hotopf M, John A, et al. Mental health before and during the COVID-19 pandemic: a longitudinal probability sample survey of the UK population. The Lancet Psychiatry 2020 Oct;7(10):883-892. [doi: 10.1016/s2215-0366(20)30308-4]

13. Betsch C, Wieler L, Bosnjak M, Ramharter M, Stollorz V, Omer S. Germany COVID-19 Snapshot MOnitoring (COSMO Germany): Monitoring knowledge, risk perceptions, preventive behaviors, and public trust in the current coronavirus outbreak in Germany. PsychArchives 2020. [doi: 10.23668/psycharchives.2776]

14. Kwong A, Pearson R, Adams M, Northstone K, Tilling K, Smith D. Mental health during the COVID-19 pandemic in two longitudinal UK population cohorts. medRxiv. Preprint posted online June 18, 2020. [doi: 10.1101/2020.06.16.20133116]

15. Betsch C, Korn L, Felgendreff L, Eitze S, Schmid P, Sprengholz P, et al. German COVID-19 Snapshot MOnitoring (COSMO Germany). PsychArchives. Preprint posted online Apr 3, 2020. [FREE Full text] [doi: 10.23668/psycharchives.2863]

16. Rauschenberg C, Schick A, Goetzl C, Roehr S, Riedel-Heller S, Koppe G. Social isolation, mental health and use of digital interventions in youth during the COVID-19 pandemic: a nationally representative survey. PsyArXiv Preprints. Preprint posted online June 29, 2020. [doi: 10.31234/osf.io/v64hf]

17. Torrent-Sellens J, Díaz-Chao A, Soler-Ramos I, Saigí-Rubió F. Modelling and Predicting eHealth Usage in Europe: A Multidimensional Approach From an Online Survey of 13,000 European Union Internet Users. J Med Internet Res 2016 Jul 22;18(7):e188 [FREE Full text] [doi: 10.2196/jmir.5605] [Medline: 27450189]

18. Simons CJP, Drukker M, Evers S, van Mastrigt GAPG, Höhn P, Kramer I, et al. Economic evaluation of an experience sampling method intervention in depression compared with treatment as usual using data from a randomized controlled trial. BMC Psychiatry 2017 Dec 29;17(1):415 [FREE Full text] [doi: 10.1186/s12888-017-1577-7] [Medline: 29284448]

19. Market study on telemedicine. European Commission. 2018 Oct. URL: https://ec.europa.eu/health/sites/health/files/ehealth/ docs/2018 provision marketstudy telemedicine en.pdf [accessed 2021-03-01]

20. Briskman J. Sensor Tower's Q1 2020 Data Digest: Exploring COVID-19's Impact on the Global App Ecosystem. Sensor Tower Inc. 2020 Apr 15. URL: https://sensortower.com/blog/q1-2020-data-digest [accessed 2021-03-01]

21. Moher D, Liberati A, Tetzlaff J, Altman DG, PRISMA Group. Preferred reporting items for systematic reviews and meta-analyses: the PRISMA statement. PLoS Med 2009 Jul 21;6(7):e1000097 [FREE Full text] [doi: 10.1371/journal.pmed.1000097] [Medline: 19621072]

22. Endnote X9 ed. Clarivate Analytics. URL: https://endnote.com/ [accessed 2021-03-01]

23. Heber E, Ebert DD, Lehr D, Cuijpers P, Berking M, Nobis S, et al. The Benefit of Web- and Computer-Based Interventions for Stress: A Systematic Review and Meta-Analysis. J Med Internet Res 2017 Feb 17;19(2):e32 [FREE Full text] [doi: 10.2196/jmir.5774] [Medline: 28213341]

24. Giroux I, Goulet A, Mercier J, Jacques C, Bouchard S. Online and Mobile Interventions for Problem Gambling, Alcohol, and Drugs: A Systematic Review. Front Psychol 2017;8:954 [FREE Full text] [doi: 10.3389/fpsyg.2017.00954] [Medline: 28649211]

25. Miralles I, Granell C, Díaz-Sanahuja L, Van Woensel W, Bretón-López J, Mira A, et al. Smartphone Apps for the Treatment of Mental Disorders: Systematic Review. JMIR Mhealth Uhealth 2020 Apr 02;8(4):e14897 [FREE Full text] [doi: 10.2196/14897] [Medline: 32238332]

26. Domhardt M, Steubl L, Baumeister H. Internet- and Mobile-Based Interventions for Mental and Somatic Conditions in Children and Adolescents. Z Kinder Jugendpsychiatr Psychother 2020 Jan 13;48(1):33-46 [FREE Full text] [doi: 10.1024/1422-4917/a000625] [Medline: 30422059]

27. Larsen ME, Huckvale K, Nicholas J, Torous J, Birrell L, Li E, et al. Using science to sell apps: Evaluation of mental health app store quality claims. NPJ Digit Med 2019;2:18 [FREE Full text] [doi: 10.1038/s41746-019-0093-1] [Medline: 31304366] 
28. Mercurio M, Larsen M, Wisniewski H, Henson P, Lagan S, Torous J. Longitudinal trends in the quality, effectiveness and attributes of highly rated smartphone health apps. Evid Based Ment Health 2020 Aug;23(3):107-111 [FREE Full text] [doi: 10.1136/ebmental-2019-300137] [Medline: 32312794]

29. Alyami M, Giri B, Alyami H, Sundram F. Social anxiety apps: a systematic review and assessment of app descriptors across mobile store platforms. Evid Based Ment Health 2017 Aug;20(3):65-70. [doi: 10.1136/eb-2017-102664] [Medline: 28666986]

30. Loucas C, Pennant M, Whittington C, Naqvi S, Sealey C, Stockton S, et al. G130 E-therapies for mental health problems in children and young people: A systematic review and focus group investigation. Archives of Disease in Childhood 2014 Apr 07;99(Suppl 1):A58-A58. [doi: 10.1136/archdischild-2014-306237.138]

31. Ennis N, Sijercic I, Monson CM. Internet-Delivered Early Interventions for Individuals Exposed to Traumatic Events: Systematic Review. J Med Internet Res 2018 Nov 14;20(11):e280 [FREE Full text] [doi: 10.2196/jmir.9795] [Medline: $\underline{30429113]}$

32. Elaheebocus SMRA, Weal M, Morrison L, Yardley L. Peer-Based Social Media Features in Behavior Change Interventions: Systematic Review. J Med Internet Res 2018 Feb 22;20(2):e20 [FREE Full text] [doi: 10.2196/jmir.8342] [Medline: 29472174]

33. Alkhaldi G, Hamilton FL, Lau R, Webster R, Michie S, Murray E. The Effectiveness of Prompts to Promote Engagement With Digital Interventions: A Systematic Review. J Med Internet Res 2016 Jan 08;18(1):e6 [FREE Full text] [doi: 10.2196/jmir.4790] [Medline: 26747176]

34. Lau PWC, Lau EY, Wong DP, Ransdell L. A systematic review of information and communication technology-based interventions for promoting physical activity behavior change in children and adolescents. J Med Internet Res 2011 Jul 13;13(3):e48 [FREE Full text] [doi: 10.2196/jmir.1533] [Medline: 21749967]

35. Cotie LM, Prince SA, Elliott CG, Ziss MC, McDonnell LA, Mullen KA, et al. The effectiveness of eHealth interventions on physical activity and measures of obesity among working-age women: a systematic review and meta-analysis. Obes Rev 2018 Oct;19(10):1340-1358. [doi: 10.1111/obr.12700] [Medline: 30156044]

36. Davies EB, Morriss R, Glazebrook C. Computer-delivered and web-based interventions to improve depression, anxiety, and psychological well-being of university students: a systematic review and meta-analysis. J Med Internet Res 2014 May 16;16(5):e130 [FREE Full text] [doi: 10.2196/jmir.3142] [Medline: 24836465]

37. Flujas-Contreras JM, García-Palacios A, Gómez I. Technology-based parenting interventions for children's physical and psychological health: a systematic review and meta-analysis. Psychol Med 2019 Aug;49(11):1787-1798. [doi:

10.1017/S0033291719000692] [Medline: 30977462]

38. Harrer M, Adam SH, Baumeister H, Cuijpers P, Karyotaki E, Auerbach RP, et al. Internet interventions for mental health in university students: A systematic review and meta-analysis. Int J Methods Psychiatr Res 2019 Jun;28(2):e1759 [FREE Full text] [doi: 10.1002/mpr.1759] [Medline: $\underline{\text { 30585363] }}$

39. Simon N, McGillivray L, Roberts NP, Barawi K, Lewis CE, Bisson JI. Acceptability of internet-based cognitive behavioural therapy (i-CBT) for post-traumatic stress disorder (PTSD): a systematic review. Eur J Psychotraumatol 2019;10(1):1646092 [FREE Full text] [doi: 10.1080/20008198.2019.1646092] [Medline: $\underline{\text { 31497259] }}$

40. Alvarez-Jimenez M, Alcazar-Corcoles MA, González-Blanch C, Bendall S, McGorry PD, Gleeson JF. Online, social media and mobile technologies for psychosis treatment: a systematic review on novel user-led interventions. Schizophr Res 2014 Jun;156(1):96-106. [doi: 10.1016/j.schres.2014.03.021] [Medline: 24746468]

41. Rost T, Stein J, Löbner M, Kersting A, Luck-Sikorski C, Riedel-Heller SG. User Acceptance of Computerized Cognitive Behavioral Therapy for Depression: Systematic Review. J Med Internet Res 2017 Sep 13;19(9):e309 [FREE Full text] [doi: 10.2196/jmir.7662] [Medline: 28903893]

42. Biagianti B, Quraishi SH, Schlosser DA. Potential Benefits of Incorporating Peer-to-Peer Interactions Into Digital Interventions for Psychotic Disorders: A Systematic Review. Psychiatr Serv 2018 Apr 01;69(4):377-388 [FREE Full text] [doi: 10.1176/appi.ps.201700283] [Medline: 29241435]

43. Aref-Adib G, McCloud T, Ross J, O'Hanlon P, Appleton V, Rowe S, et al. Factors affecting implementation of digital health interventions for people with psychosis or bipolar disorder, and their family and friends: a systematic review. The Lancet Psychiatry 2019 Mar;6(3):257-266. [doi: 10.1016/S2215-0366(18)30302-X] [Medline: 30522979]

44. Goldberg SB, Buck B, Raphaely S, Fortney JC. Measuring Psychiatric Symptoms Remotely: a Systematic Review of Remote Measurement-Based Care. Curr Psychiatry Rep 2018 Aug 28;20(10):81. [doi: 10.1007/s11920-018-0958-z] [Medline: 30155749]

45. Faurholt-Jepsen M, Munkholm K, Frost M, Bardram JE, Kessing LV. Electronic self-monitoring of mood using IT platforms in adult patients with bipolar disorder: A systematic review of the validity and evidence. BMC Psychiatry 2016;16:7 [FREE Full text] [doi: 10.1186/s12888-016-0713-0] [Medline: 26769120]

46. Erbe D, Eichert H, Riper H, Ebert DD. Blending Face-to-Face and Internet-Based Interventions for the Treatment of Mental Disorders in Adults: Systematic Review. J Med Internet Res 2017 Sep 15;19(9):e306 [FREE Full text] [doi: 10.2196/jmir.6588] [Medline: 28916506]

47. Walsh S, Golden E, Priebe S. Systematic review of patients' participation in and experiences of technology-based monitoring of mental health symptoms in the community. BMJ Open 2016 Jun 21;6(6):e008362 [FREE Full text] [doi:

10.1136/bmjopen-2015-008362] [Medline: 27329437] 
48. Pravettoni G, Triberti S. P5 eHealth: An Agenda for the Health Technologies of the Future. Cham: Springer International Publishing; 2020.

49. Hutton L, Price BA, Kelly R, McCormick C, Bandara AK, Hatzakis T, et al. Assessing the Privacy of mHealth Apps for Self-Tracking: Heuristic Evaluation Approach. JMIR Mhealth Uhealth 2018 Oct 22;6(10):e185 [FREE Full text] [doi: 10.2196/mhealth.9217] [Medline: $\underline{30348623}$ ]

50. Arguel A, Perez-Concha O, Li SYW, Lau AYS. Theoretical approaches of online social network interventions and implications for behavioral change: a systematic review. J Eval Clin Pract 2018 Feb;24(1):212-221. [doi: 10.1111/jep.12655] [Medline: 27709724]

51. Massoudi B, Holvast F, Bockting CLH, Burger H, Blanker MH. The effectiveness and cost-effectiveness of e-health interventions for depression and anxiety in primary care: A systematic review and meta-analysis. J Affect Disord 2019 Feb 15;245:728-743. [doi: 10.1016/j.jad.2018.11.050] [Medline: 30447572]

52. Pennant ME, Loucas CE, Whittington C, Creswell C, Fonagy P, Fuggle P, Expert Advisory Group. Computerised therapies for anxiety and depression in children and young people: a systematic review and meta-analysis. Behav Res Ther 2015 Apr;67:1-18. [doi: 10.1016/j.brat.2015.01.009] [Medline: 25727678]

53. Chebli J, Blaszczynski A, Gainsbury SM. Internet-Based Interventions for Addictive Behaviours: A Systematic Review. J Gambl Stud 2016 Dec;32(4):1279-1304. [doi: 10.1007/s10899-016-9599-5] [Medline: 27002522]

54. Hadjistavropoulos HD, Mehta S, Wilhelms A, Keough MT, Sundström C. A systematic review of internet-delivered cognitive behavior therapy for alcohol misuse: study characteristics, program content and outcomes. Cogn Behav Ther 2020 Jul;49(4):327-346. [doi: 10.1080/16506073.2019.1663258] [Medline: 31599198 ]

55. O'Rourke L, Humphris G, Baldacchino A. Electronic communication based interventions for hazardous young drinkers: A systematic review. Neurosci Biobehav Rev 2016 Dec;68:880-890. [doi: 10.1016/j.neubiorev.2016.07.021] [Medline: 27453570]

56. Tait RJ, Christensen H. Internet-based interventions for young people with problematic substance use: a systematic review. Med J Aust 2010 Jun 07;192(S11):S15-S21. [doi: 10.5694/j.1326-5377.2010.tb03687.x] [Medline: 20528701]

57. Boumparis N, Loheide-Niesmann L, Blankers M, Ebert DD, Korf D, Schaub MP, et al. Short- and long-term effects of digital prevention and treatment interventions for cannabis use reduction: A systematic review and meta-analysis. Drug Alcohol Depend 2019 Jul 01;200:82-94 [FREE Full text] [doi: 10.1016/j.drugalcdep.2019.03.016] [Medline: 31112834]

58. Asuzu K, Matin A, Van Noord M, Onigu-Otite E. Electronically-Delivered Interventions to Reduce Cannabis Use in Adolescents: A Systematic Review. APS 2019 Jan 31;8(3):195-213. [doi: 10.2174/2210676609666181203094249]

59. Deady M, Choi I, Calvo RA, Glozier N, Christensen H, Harvey SB. eHealth interventions for the prevention of depression and anxiety in the general population: a systematic review and meta-analysis. BMC Psychiatry 2017 Aug 29;17(1):310 [FREE Full text] [doi: 10.1186/s12888-017-1473-1] [Medline: 28851342]

60. Richardson T, Stallard P, Velleman S. Computerised cognitive behavioural therapy for the prevention and treatment of depression and anxiety in children and adolescents: a systematic review. Clin Child Fam Psychol Rev 2010 Sep;13(3):275-290. [doi: 10.1007/s10567-010-0069-9] [Medline: 20532980]

61. Fleming TM, Cheek C, Merry SN, Thabrew H, Bridgman H, Stasiak K, et al. Juegos serios para el tratamiento o la prevención de la depresión: una revisión sistemática. RPPC 2014;19(3):227-242. [doi: 10.5944/rppc.vol.19.num.3.2014.13904]

62. Lau HM, Smit JH, Fleming TM, Riper H. Serious Games for Mental Health: Are They Accessible, Feasible, and Effective? A Systematic Review and Meta-analysis. Front Psychiatry 2016;7:209 [FREE Full text] [doi: 10.3389/fpsyt.2016.00209] [Medline: 28149281]

63. Grist R, Croker A, Denne M, Stallard P. Technology Delivered Interventions for Depression and Anxiety in Children and Adolescents: A Systematic Review and Meta-analysis. Clin Child Fam Psychol Rev 2019 Jun;22(2):147-171 [FREE Full text] [doi: 10.1007/s10567-018-0271-8] [Medline: 30229343]

64. Baker S, Warburton J, Waycott J, Batchelor F, Hoang T, Dow B, et al. Combatting social isolation and increasing social participation of older adults through the use of technology: A systematic review of existing evidence. Australas $\mathbf{J}$ Ageing 2018 Sep;37(3):184-193. [doi: 10.1111/ajag.12572] [Medline: 30022583]

65. Grist R, Cavanagh K. Computerised Cognitive Behavioural Therapy for Common Mental Health Disorders, What Works, for Whom Under What Circumstances? A Systematic Review and Meta-analysis. J Contemp Psychother 2013 Sep 4;43(4):243-251. [doi: 10.1007/s10879-013-9243-y]

66. Păsărelu CR, Andersson G, Bergman Nordgren L, Dobrean A. Internet-delivered transdiagnostic and tailored cognitive behavioral therapy for anxiety and depression: a systematic review and meta-analysis of randomized controlled trials. Cogn Behav Ther 2017 Jan;46(1):1-28. [doi: 10.1080/16506073.2016.1231219] [Medline: 27712544]

67. Ye X, Bapuji SB, Winters SE, Struthers A, Raynard M, Metge C, et al. Effectiveness of internet-based interventions for children, youth, and young adults with anxiety and/or depression: a systematic review and meta-analysis. BMC Health Serv Res 2014 Jul 18;14:313 [FREE Full text] [doi: 10.1186/1472-6963-14-313] [Medline: 25037951]

68. Stech EP, Lim J, Upton EL, Newby JM. Internet-delivered cognitive behavioral therapy for panic disorder with or without agoraphobia: a systematic review and meta-analysis. Cogn Behav Ther 2020 Jul;49(4):270-293. [doi: 10.1080/16506073.2019.1628808] [Medline: 31303121] 
69. Rice SM, Goodall J, Hetrick SE, Parker AG, Gilbertson T, Amminger GP, et al. Online and social networking interventions for the treatment of depression in young people: a systematic review. J Med Internet Res 2014 Sep 16;16(9):e206 [FREE Full text] [doi: 10.2196/jmir.3304] [Medline: 25226790]

70. Richards D, Richardson T. Computer-based psychological treatments for depression: a systematic review and meta-analysis. Clin Psychol Rev 2012 Jun;32(4):329-342. [doi: 10.1016/j.cpr.2012.02.004] [Medline: 22466510]

71. Wright JH, Owen JJ, Richards D, Eells TD, Richardson T, Brown GK, et al. Computer-Assisted Cognitive-Behavior Therapy for Depression: A Systematic Review and Meta-Analysis. J Clin Psychiatry 2019 Mar 19;80(2) [FREE Full text] [doi: 10.4088/JCP.18r12188] [Medline: 30900849]

72. Sikorski C, Luppa M, Kersting A, König HH, Riedel-Heller SG. [Computer-aided cognitive behavioral therapy for depression]. Psychiatr Prax 2011 Feb;38(2):61-68. [doi: 10.1055/s-0030-1248575] [Medline: 20972949]

73. Xiang X, Wu S, Zuverink A, Tomasino KN, An R, Himle JA. Internet-delivered cognitive behavioral therapies for late-life depressive symptoms: a systematic review and meta-analysis. Aging Ment Health 2020 Aug 27;24(8):1196-1206. [doi: 10.1080/13607863.2019.1590309] [Medline: 30913898]

74. Danielsson A, Eriksson A, Allebeck P. Technology-based support via telephone or web: a systematic review of the effects on smoking, alcohol use and gambling. Addict Behav 2014 Dec;39(12):1846-1868. [doi: 10.1016/j.addbeh.2014.06.007] [Medline: 25128637]

75. Lin LA, Casteel D, Shigekawa E, Weyrich MS, Roby DH, McMenamin SB. Telemedicine-delivered treatment interventions for substance use disorders: A systematic review. J Subst Abuse Treat 2019 Jun;101:38-49. [doi: 10.1016/j.jsat.2019.03.007] [Medline: 31006553 ]

76. Gilmore AK, Wilson SM, Skopp NA, Osenbach JE, Reger G. A systematic review of technology-based interventions for co-occurring substance use and trauma symptoms. J Telemed Telecare 2017 Sep;23(8):701-709. [doi:

10.1177/1357633X16664205] [Medline: 27534823]

77. Pittock A, Hodges L, Lawrie SM. The effectiveness of internet-delivered cognitive behavioural therapy for those with bulimic symptoms: a systematic review : A review of iCBT treatment for bulimic symptoms. BMC Res Notes 2018 Oct 22;11(1):748 [FREE Full text] [doi: 10.1186/s13104-018-3843-2] [Medline: 30348226]

78. Meyer TD, Casarez R, Mohite SS, La Rosa N, Iyengar MS. Novel technology as platform for interventions for caregivers and individuals with severe mental health illnesses: A systematic review. J Affect Disord 2018 Jan 15;226:169-177. [doi: 10.1016/j.jad.2017.09.012] [Medline: 28987999]

79. Sierra M, Ruiz F, Flórez C. A Systematic Review and Meta-Analysis of Third-Wave Online Interventions for Depression. RLP 2018 Sep 30;50(2):1641-1648. [doi: 10.14349/rlp.2018.v50.n2.6]

80. Berryhill MB, Halli-Tierney A, Culmer N, Williams N, Betancourt A, King M, et al. Videoconferencing psychological therapy and anxiety: a systematic review. Fam Pract 2019 Jan 25;36(1):53-63. [doi: 10.1093/fampra/cmy072] [Medline: 30188992]

81. Castro A, Gili M, Ricci-Cabello I, Roca M, Gilbody S, Perez-Ara MA, et al. Effectiveness and adherence of telephone-administered psychotherapy for depression: A systematic review and meta-analysis. J Affect Disord 2020 Jan 01;260:514-526. [doi: 10.1016/i.jad.2019.09.023] [Medline: $\underline{31539688]}$

82. Coughtrey AE, Pistrang N. The effectiveness of telephone-delivered psychological therapies for depression and anxiety: A systematic review. J Telemed Telecare 2016 Dec 30;24(2):65-74. [doi: 10.1177/1357633x16686547]

83. Rees C, Maclaine E. A Systematic Review of Videoconference-Delivered Psychological Treatment for Anxiety Disorders. Australian Psychologist 2015 Jul 20;50(4):259-264. [doi: 10.1111/ap.12122]

84. Bolton AJ, Dorstyn DS. Telepsychology for Posttraumatic Stress Disorder: A systematic review. J Telemed Telecare 2015 Jul;21(5):254-267. [doi: 10.1177/1357633X15571996] [Medline: 25712113]

85. Lewis C, Roberts NP, Simon N, Bethell A, Bisson JI. Internet-delivered cognitive behavioural therapy for post-traumatic stress disorder: systematic review and meta-analysis. Acta Psychiatr Scand 2019 Dec;140(6):508-521. [doi: 10.1111/acps.13079] [Medline: $\underline{31359407]}$

86. Baker AL, Turner A, Beck A, Berry K, Haddock G, Kelly PJ, et al. Telephone-delivered psychosocial interventions targeting key health priorities in adults with a psychotic disorder: systematic review. Psychol Med 2018 Dec 25;48(16):2637-2657 [FREE Full text] [doi: 10.1017/S0033291718001125] [Medline: 29798730]

87. Gentry MT, Lapid MI, Clark MM, Rummans TA. Evidence for telehealth group-based treatment: A systematic review. J Telemed Telecare 2019 Jul;25(6):327-342. [doi: 10.1177/1357633X18775855] [Medline: 29788807]

88. Irvine A, Drew P, Bower P, Brooks H, Gellatly J, Armitage CJ, et al. Are there interactional differences between telephone and face-to-face psychological therapy? A systematic review of comparative studies. J Affect Disord 2020 Mar 15;265:120-131 [FREE Full text] [doi: 10.1016/j.jad.2020.01.057] [Medline: 32090733]

89. Baker TB, Gustafson DH, Shah D. How can research keep up with eHealth? Ten strategies for increasing the timeliness and usefulness of eHealth research. J Med Internet Res 2014 Feb 19;16(2):e36 [FREE Full text] [doi: 10.2196/jmir.2925] [Medline: 24554442]

90. Böhm B, Karwiese SD, Böhm H, Oberhoffer R. Effects of Mobile Health Including Wearable Activity Trackers to Increase Physical Activity Outcomes Among Healthy Children and Adolescents: Systematic Review. JMIR Mhealth Uhealth 2019 Apr 30;7(4):e8298 [FREE Full text] [doi: 10.2196/mhealth.8298] [Medline: $\underline{\text { 31038460] }}$ 
91. Bort-Roig J, Gilson ND, Puig-Ribera A, Contreras RS, Trost SG. Measuring and influencing physical activity with smartphone technology: a systematic review. Sports Med 2014 May;44(5):671-686. [doi: 10.1007/s40279-014-0142-5] [Medline: 24497157]

92. Feter N, Dos Santos TS, Caputo EL, da Silva MC. What is the role of smartphones on physical activity promotion? A systematic review and meta-analysis. Int J Public Health 2019 Jun;64(5):679-690. [doi: 10.1007/s00038-019-01210-7] [Medline: 30758514]

93. Kim H, Seo K. Smartphone-Based Health Program for Improving Physical Activity and Tackling Obesity for Young Adults: A Systematic Review and Meta-Analysis. Int J Environ Res Public Health 2019 Dec 18;17(1):15 [FREE Full text] [doi: 10.3390/ijerph17010015] [Medline: 31861359]

94. Rose T, Barker M, Maria Jacob C, Morrison L, Lawrence W, Strömmer S, et al. A Systematic Review of Digital Interventions for Improving the Diet and Physical Activity Behaviors of Adolescents. J Adolesc Health 2017 Dec;61(6):669-677 [FREE Full text] [doi: 10.1016/j.jadohealth.2017.05.024] [Medline: 28822682]

95. Muntaner A, Vidal-Conti J, Palou P. Increasing physical activity through mobile device interventions: A systematic review. Health Informatics J 2016 Sep 3;22(3):451-469 [FREE Full text] [doi: 10.1177/1460458214567004] [Medline: 25649783]

96. Donker T, Petrie K, Proudfoot J, Clarke J, Birch M, Christensen H. Smartphones for smarter delivery of mental health programs: a systematic review. J Med Internet Res 2013 Nov 15;15(11):e247 [FREE Full text] [doi: 10.2196/jmir.2791] [Medline: 24240579]

97. Loo Gee B, Griffiths KM, Gulliver A. Effectiveness of mobile technologies delivering Ecological Momentary Interventions for stress and anxiety: a systematic review. J Am Med Inform Assoc 2016 Jan;23(1):221-229 [FREE Full text] [doi: 10.1093/jamia/ocv043] [Medline: 25997643]

98. Holmes NA, van Agteren JE, Dorstyn DS. A systematic review of technology-assisted interventions for co-morbid depression and substance use. J Telemed Telecare 2019 Apr;25(3):131-141. [doi: 10.1177/1357633X17748991] [Medline: 29310532]

99. Rathbone AL, Prescott J. The Use of Mobile Apps and SMS Messaging as Physical and Mental Health Interventions: Systematic Review. J Med Internet Res 2017 Aug 24;19(8):e295 [FREE Full text] [doi: 10.2196/jmir.7740] [Medline: 28838887]

100. Rootes-Murdy K, Glazer KL, Van Wert MJ, Mondimore FM, Zandi PP. Mobile technology for medication adherence in people with mood disorders: A systematic review. J Affect Disord 2018 Feb;227:613-617. [doi: 10.1016/j.jad.2017.11.022] [Medline: 29172054]

101. Dick S, Whelan E, Davoren MP, Dockray S, Heavin C, Linehan C, et al. A systematic review of the effectiveness of digital interventions for illicit substance misuse harm reduction in third-level students. BMC Public Health 2019 Sep 09;19(1):1244 [FREE Full text] [doi: 10.1186/s12889-019-7583-6] [Medline: 31500618]

102. Song T, Qian S, Yu P. Mobile Health Interventions for Self-Control of Unhealthy Alcohol Use: Systematic Review. JMIR Mhealth Uhealth 2019 Jan 29;7(1):e10899 [FREE Full text] [doi: 10.2196/10899] [Medline: $\underline{\text { 30694200] }}$

103. Yonker LM, Zan S, Scirica CV, Jethwani K, Kinane TB. "Friending" teens: systematic review of social media in adolescent and young adult health care. J Med Internet Res 2015 Jan 05;17(1):e4 [FREE Full text] [doi: 10.2196/jmir.3692] [Medline: 25560751]

104. Arshad U, Farhat-Ul-Ain, Gauntlett J, Husain N, Chaudhry N, Taylor PJ. A Systematic Review of the Evidence Supporting Mobile- and Internet-Based Psychological Interventions For Self-Harm. Suicide Life Threat Behav 2020 Feb;50(1):151-179 [FREE Full text] [doi: 10.1111/sltb.12583] [Medline: 31448847]

105. Clarke S, Hanna D, Mulholland C, Shannon C, Urquhart C. A systematic review and meta-analysis of digital health technologies effects on psychotic symptoms in adults with psychosis. Psychosis 2019 Aug 12;11(4):362-373. [doi: $10.1080 / 17522439.2019 .1632376]$

106. Kreuze E, Jenkins C, Gregoski M, York J, Mueller M, Lamis DA, et al. Technology-enhanced suicide prevention interventions: A systematic review. J Telemed Telecare 2017 Jul;23(6):605-617. [doi: 10.1177/1357633X16657928] [Medline: 27377792]

107. Perry Y, Werner-Seidler A, Calear AL, Christensen H. Web-Based and Mobile Suicide Prevention Interventions for Young People: A Systematic Review. J Can Acad Child Adolesc Psychiatry 2016;25(2):73-79 [FREE Full text] [Medline: 27274742]

108. Ilagan GS, Iliakis EA, Wilks CR, Vahia IV, Choi-Kain LW. Smartphone applications targeting borderline personality disorder symptoms: a systematic review and meta-analysis. Borderline Personal Disord Emot Dysregul 2020;7:12 [FREE Full text] [doi: 10.1186/s40479-020-00127-5] [Medline: $\underline{32549987]}$

109. Sander LB, Schorndanner J, Terhorst Y, Spanhel K, Pryss R, Baumeister H, et al. 'Help for trauma from the app stores?' A systematic review and standardised rating of apps for Post-Traumatic Stress Disorder (PTSD). Eur J Psychotraumatol 2020;11(1):1701788 [FREE Full text] [doi: 10.1080/20008198.2019.1701788] [Medline: $\underline{\text { 32002136] }}$

110. Sucala M, Cuijpers P, Muench F, Cardo R, Soflau R, Dobrean A, et al. Anxiety: There is an app for that. A systematic review of anxiety apps. Depress Anxiety 2017 Jun;34(6):518-525. [doi: 10.1002/da.22654] [Medline: 28504859]

111. Terhorst Y, Rathner E, Baumeister H, Sander L. «Hilfe aus dem App-Store?»: Eine systematische Übersichtsarbeit und Evaluation von Apps zur Anwendung bei Depressionen. Verhaltenstherapie 2018 May 8;28(2):101-112. [doi:

10.1159/000481692] 
112. Axelsson E, Hedman-Lagerlöf E. Cognitive behavior therapy for health anxiety: systematic review and meta-analysis of clinical efficacy and health economic outcomes. Expert Rev Pharmacoecon Outcomes Res 2019 Dec;19(6):663-676. [doi: 10.1080/14737167.2019.1703182] [Medline: 31859542]

113. Hedman E, Ljótsson B, Lindefors N. Cognitive behavior therapy via the Internet: a systematic review of applications, clinical efficacy and cost-effectiveness. Expert Rev Pharmacoecon Outcomes Res 2012 Dec;12(6):745-764. [doi: 10.1586/erp.12.67] [Medline: 23252357]

114. Edwards EA, Lumsden J, Rivas C, Steed L, Edwards LA, Thiyagarajan A, et al. Gamification for health promotion: systematic review of behaviour change techniques in smartphone apps. BMJ Open 2016 Oct 04;6(10):e012447 [FREE Full text] [doi: 10.1136/bmjopen-2016-012447] [Medline: 27707829]

115. Berry N, Lobban F, Emsley R, Bucci S. Acceptability of Interventions Delivered Online and Through Mobile Phones for People Who Experience Severe Mental Health Problems: A Systematic Review. J Med Internet Res 2016 May 31;18(5):e121 [FREE Full text] [doi: 10.2196/jmir.5250] [Medline: 27245693]

116. Mantovani E, Antokol J, Hoekstra M, Nouwt S, Schutte N, Zilgalvis P. Towards a Code of Conduct on Privacy for mHealth to Foster Trust Amongst Users of Mobile Health Applications. In: Leenes R, van Brakel R, Gutwirth S, De Hert P, editors. Data Protection and Privacy: (In)visibilities and Infrastructures. Cham: Springer International Publishing; 2017:81-106.

117. Soron TR, Shariful Islam SM, Ahmed HU, Ahmed SI. The hope and hype of telepsychiatry during the COVID-19 pandemic. The Lancet Psychiatry 2020 Aug;7(8):e50 [FREE Full text] [doi: 10.1016/S2215-0366(20)30260-1] [Medline: 32711713]

118. Shea BJ, Reeves BC, Wells G, Thuku M, Hamel C, Moran J, et al. AMSTAR 2: a critical appraisal tool for systematic reviews that include randomised or non-randomised studies of healthcare interventions, or both. BMJ 2017 Sep 21;358:j4008 [FREE Full text] [doi: 10.1136/bmj.j4008] [Medline: 28935701]

119. Tricco AC, Antony J, Zarin W, Strifler L, Ghassemi M, Ivory J, et al. A scoping review of rapid review methods. BMC Med 2015 Sep 16;13:224 [FREE Full text] [doi: 10.1186/s12916-015-0465-6] [Medline: 26377409]

120. Rapid reviews to strengthen health policy and systems: a practical guide. World Health Organization, Alliance for Health Policy and Systems Research. 2017. URL: https://www.who.int/alliance-hpsr/resources/publications/rapid-review-guide/ en/ [accessed 2021-03-01]

121. Digital health applications (DiGA). Federal Institute for Drugs and Medical Devices (BfArM), Germany. 2020. URL: https:/ /www.bfarm.de/EN/MedicalDevices/DiGA/ node.html [accessed 2021-03-01]

122. Apps Library - Category Mental Health. United Kingdom National Health Service. 2020. URL: https://www.nhs.uk/ apps-library/filter/?categories=Mental\%20health [accessed 2021-03-01]

123. App Evaluation Database. Division of Digital Psychiatry, Beth Israel Deaconess Medical Center. 2020. URL: https://apps. digitalpsych.org [accessed 2021-03-01]

\section{Abbreviations}

AMSTAR 2: A Measurement Tool to Assess Systematic Reviews

CBT: cognitive-behavioral therapy

COSMO Germany: German COVID-19 Snapshot Monitoring

IT: information technology

mHealth: mobile health

PRISMA: Preferred Reporting Items for Systematic Reviews and Meta-Analyses

Edited by G Eysenbach, C Basch; submitted 10.08.20; peer-reviewed by B Buck, A Beck, A Salzwedel, S Elaheebocus; comments to
author 19.09.20; revised version received 14.02.21; accepted 17.02.21; published 10.03.21
Please cite as:
Rauschenberg C, Schick A, Hirjak D, Seidler A, Paetzold I, Apfelbacher C, Riedel-Heller SG, Reininghaus U
Evidence Synthesis of Digital Interventions to Mitigate the Negative Impact of the COVID-19 Pandemic on Public Mental Health:
Rapid Meta-review
J Med Internet Res 2021;23(3):e23365
URL: $\underline{\text { https://www.jmir.org/2021/3/e23365 }}$
doi: $\underline{10.2196 / 23365}$
PMID: $\underline{33606657}$

(C) Christian Rauschenberg, Anita Schick, Dusan Hirjak, Andreas Seidler, Isabell Paetzold, Christian Apfelbacher, Steffi G Riedel-Heller, Ulrich Reininghaus. Originally published in the Journal of Medical Internet Research (http://www.jmir.org), 10.03.2021. This is an open-access article distributed under the terms of the Creative Commons Attribution License (https://creativecommons.org/licenses/by/4.0/), which permits unrestricted use, distribution, and reproduction in any medium, 
provided the original work, first published in the Journal of Medical Internet Research, is properly cited. The complete bibliographic information, a link to the original publication on http://www.jmir.org/, as well as this copyright and license information must be included. 